Assiut University web-site: www.aun.edu.eg

\title{
EFFECT OF USING FORMIC ACID ON GROWTH PERFORMANCE AND SOME BLOOD PARAMETER OF BROILER CHICKEN
}

\author{
H.A. MAHMOUD; O.S. AFIFFY AND M. MAHROUS \\ Department of Poultry Production, Faculty of Agriculture, Assiut University, Assiut, Egypt
}

Received: 21 November 2019; Accepted: 30 January 2020

\begin{abstract}
The aim of this study was conducted to evaluate the efficiency of formic acid supplementation as growth promoters in broiler chicken. The study was carried out utilizing $132 \mathrm{Cobb}$ commercial broiler chicks which were randomly assigned into two groups one having three levels of formic acid and the other one as control. Each level contained 2 replicates of 11 chicks each. Birds in tow groups were fed basal diet (starter and grower) whereas birds in formic acid treatment were received water with $0.5,0.75$ and $1 \%$ formic acid. Results revealed that the birds supplemented with formic acids had significantly $(p<0.0001)$ lower body weight (BW) and higher body weight gains (BWG) at the levels of 0.75 and $1.0 \%$ at 35 days of age. Cumulative feed consumption was decreased $(p<0.0001)$ in the groups supplemented formic acids compared to control group which had high feed intake. Supplementation of formic acid improved $(p<0.0001)$ the feed conversion ratio (FCR) as compared with control group. Increased total fat and bursa weight were observed in groups fed formic acid while, the breast yield and dressed carcass were decreased. Addition of formic acid at level of $1 \%$ to the diets of broiler chicken decreased $(p<0.001)$ the caecal viable and coliform counts compared to the un-supplemented group. The $\mathrm{pH}$ was decrease in formic acid treated group.
\end{abstract}

Key words: Broiler chicken, growth, bacteria population, formic acid.

\section{INTRODUCTION}

The key aim of poultry production for the food chain is to obtain proper growth rate and feed conversion efficiency, while maintaining optimal animal health. To achieve this, different feed additives have been produced and offered to poultry market. Recently, poultry industry has paid more attention towards addressing public concern for environmental and food safety. Thus, the non-prescription use of antibiotics in poultry feeds has been eliminated or

Corresponding author: Dr. H.A. MAHMOUD E-mail address: hussein1905@yahoo.com

Present address: Department of Poultry Production, Faculty of Agriculture, Assiut University, Assiut, Egypt severely limited. One of the potent feed additives in poultry nutrition is organic acids (OA). Recently, these compounds have been recently investigated by several authors (Gunal et al., 2006; Abdel-Fattah et al., 2008; Biggs and Parsons, 2008) and it has been shown that OA can improve poultry productivity.

Organic acids are used in feeds for their various beneficial effects on gut function and microflora, feed preservation from microbial invasion, inhibition of pathogenic bacteria, enhancing mineral absorption, accelerating recovery from cage fatigue and improvement of nutrient digestibility (Syed et al., 1994; Abdel-Azeem et al., 2000; Fushimi et al., 2001; Dibner and Buttin, 
2002; Gornowicz and Dziadek, 2002; Abdo, 2004; Ricke, 2003; Jahanian and Golshadi, 2015). Organic acids and their salts are generally regarded as safe (GRAS) and have been approved by most member states of the EU to be used as feed additives in animal production. Organic acids have growth promoting properties and can be used as alternatives to antibiotics (Patten and Waldroup 1988). Following organic acid feeding, reduction in gastric $\mathrm{pH}$ occurs which may increase the pepsin activity (Kirchgessner and Roth 1982) and the peptides arising from pepsin proteolysis trigger the release of hormones, including gastrin and cholecystokinin, which regulate the digestion and absorption of protein (Hersey 1987). The present study was carried on with the objectives to determine the effect of formic acid supplementation on the growth performance and intestinal microflora of broiler chicken.

\section{MATERIALS AND METHODS}

A total number of 132 one-day old Cobb broiler chicks were used in this study. All chicks were wing banded, individually weighed and randomly distributed into 2 groups, (1 controls and formic acid treatment). Each group included three level of organic acids. Each level included 2 replicates of 11 chicks each. Each replicate was kept in a partition of 2 square meter provided with wheat straw litter of $5 \mathrm{~cm}$ depth. The chicks were maintained under a regimen of 24 hours continuous lighting (Incandescence lambs, 60 watts at $180 \mathrm{~cm}$ from the floor) with ad-libitum feed and water.

The feeding program consisted of a starter diet until 15 days and a grower diet until 35 days of age. The composition of basal diet is shown in Table 1. Birds in the control group were given diets without additives (T1). The other treatment was given the same diets as fed to the control groups, but supplemented with $0.5,0.75$ and $1 \%$ formic acid (T2). The chemical analysis of feed samples was done as per
AOAC (1996). The dietary ingredients were analyzed for crude protein, crude fiber, ether extract and total ash. The body weight of birds per replicate was recorded on individual basis at weekly intervals. Cumulative feed consumption per replicate was also recorded on weekly basis. Feed conversion ratio per replicate was worked out at weekly intervals by taking into consideration weekly body weight gain and feed consumption of respective replicate.

At 35 days of age, six birds per group (one bird from each replicate) around the average weight of the group were taken and slaughtered as a representative sample. Birds were fasted for 8 hours, and then were slaughtered. After slaughtering, the internal organs (heart, liver, empty gizzard and gall- bladder) were removed from the body and then they were weighed. The head, feet and shanks, wings and skin were removed at the occipital bone, hock joints, shoulder joints, and neck close to the shoulder, respectively and then all were individually weighed. Breast (with and without the bones of sternum and ribs), femurs and drumsticks were also weighed as separate carcass parts. The back was separated from breast along the vertebral column. Carcass criteria (weights of carcass, feet and shanks, drumsticks, femurs, drumsticks and femurs, breast and back) were calculated as a percentage of pre-slaughter live body weight. While body organs (heart, liver, full gizzard and gall-bladder) were calculated as a percentage of carcass weight. The fat of abdomen, neck, gizzard, heart, proventriculus, vent and subcutaneous fat were removed and weighed. The fat contents were calculated as a percentage of carcass weight.

blood samples were collected during slaughter period. An aliquot of $3 \mathrm{~mL}$ of blood was collected and transferred to sterile tubes without anticoagulant. The collected blood 
samples were submitted in insulated boxes to the Microbiology Lab at Faculty of Medicine. Upon arrival, samples were centrifuged at $720 \mathrm{xg}$ for 10 minutes. The obtained sera were transferred to micro tubes and stored under refrigeration $\left(2^{\circ}\right.$ to $\left.8^{\circ} \mathrm{C}\right)$ for 24 hours until serum biochemical analyses. Levels of total protein (biuret method), albumin (bromocresol green method), globulins (calculated as the difference between the total protein and albumin were determined in individual samples in an automatic analyzer and using commercial kits.

The caecum and ileum of each bird were carefully removed and intestinal contents were immediately collected from the slaughtered bird samples were taken and transferred to the sterile tubes and placed on ice and immediately sent to the Microbiology Lab at Faculty of Medicine to determine the counts of total bacterial and gram negative bacterial counts. Each sample was serially diluted from initial 101 to $10-9$. Then, $100 \mu \mathrm{L}$ of diluted samples were plated on the Eosin Methylene Blue (EMB) (for E. Coli) and De Man, Rogosa and Sharpe (MRS) (for Lactobacillus) agar media. Finally, EMB and MRS media were incubated at $37^{\circ} \mathrm{C}$ for 24 and 48 hours under anaerobic and aerobic conditions, respectively. The results are shown as colony forming unit (CFU) per gram of cecal digesta. (Weinack et al., 1979).

The data obtained were statistically expressed as means \pm standard error and assessed by General Linear Model procedure of Data were SAS software (SAS institute, version 6. 2, 1996). Duncan's multiple range test (Duncan, 1955) was used to detect differences among means of different groups. 
Table 1: Composition and calculated analysis of the experimental diets.

\begin{tabular}{|c|c|c|}
\hline Ingredient \% & Starter diet & Grower diet \\
\hline Yellow corn, ground & $53.30 \%$ & $\% 0 \wedge, 10$ \\
\hline Soybean meal $(44 \% \mathrm{CP})$ & $35.10 \%$ & $\% \Upsilon^{\Upsilon q, 7}$ \\
\hline Corn gluten meal $(60 \% \mathrm{CP})$ & $5.50 \%$ & $\% 0,0$. \\
\hline Vit. \& Min. Premix ${ }^{*}$ & 0.30 & 0.30 \\
\hline Sunflower oil & $1.90 \%$ & $\%$ \%,r \\
\hline Dicalcium phosphate & $2.00 \%$ & $\% 1, \vee 0$ \\
\hline Limestone & $1.04 \%$ & $\% \cdot, 90$ \\
\hline Salt & $0.3 \%$ & $\% \cdot, r$ \\
\hline L- lysine & $\% \cdot r$ & $\% \cdot, Y_{0}$ \\
\hline DL- methionine & $\% \cdot, r)$ & $\% \cdot, r \cdot$ \\
\hline Total & 100 & 100 \\
\hline \multicolumn{3}{|l|}{ Calculated Analysis } \\
\hline ME, Kcal/Kg & $3 \cdots$ & rl. \\
\hline Crude Protein, (\%) & r & Y) \\
\hline Crude Fiber, $(\%)$ & 2.88 & $r, 90$ \\
\hline Crude Fat, (\%) & 5.87 & $7, \varepsilon$ \\
\hline Ca, $(\%)$ & 1.05 & $1, \cdot Y$ \\
\hline P (Available, \%) & 0.39 & $\cdot, \varepsilon$ \\
\hline Lysine, $(\%)$ & 0.75 & 0.71 \\
\hline Methionine, $(\%)$ & 0.37 & 0.32 \\
\hline
\end{tabular}

*Vitamins and minerals premix provided per Kilogram of the diet: Vit A, 10.000 IU; Vit $\mathrm{D}_{3}, 2000$ IU; Vit E, 10 mg; Vit K3 1 mg; Vit B1, 10 mg; Vit B2, 5 mg; Vit B6, 15000 mg; Vit B12, 10 mg; Nicotinic acid, $30 \mathrm{mg}$; Pantothenic acid, $10 \mathrm{mg}$; Folic acid, $1 \mathrm{mg}$; Biotin, $50 \mathrm{mcg}$; Chlorine chloride 50\%, $500 \mathrm{mg}$; Iron, $50 \mathrm{mg}$; Copper, $10 \mathrm{mg}$; Zinc, $50 \mathrm{mg}$; Manganese, $60 \mathrm{mg}$; Iodine, 10 $\mathrm{mg}$; Selenium, $0.1 \mathrm{mg} ;{ }^{* *}$ Calculated according to the NRC (1994) 


\section{RESULTS}

Table 2: The effects of different level of formic acid on growth performance at 35 days of age

\begin{tabular}{cccccc}
\hline Levels & BW & BWG & FI & FCR & FE \\
\hline Control & $2000.25^{\mathrm{a}} \pm 47.66$ & $570.70^{\mathrm{b}} \pm 28.82$ & $1058.00^{\mathrm{b}} \pm 4.93$ & $1.85^{\mathrm{b}} \pm 0.12$ & $0.54^{\mathrm{b}} \pm 0.03$ \\
\hline $\begin{array}{c}\text { Formic acid } \\
(\mathbf{0 . 5 \%})\end{array}$ & $1742.25^{\mathrm{b}} \pm 81.21$ & $427.10^{\mathrm{c}} \pm 46.72$ & $915.43^{\mathrm{a}} \pm 6.55$ & $2.14^{\mathrm{b}} \pm 0.28$ & $0.47^{\mathrm{c}} \pm 0.07$ \\
\hline $\begin{array}{c}\text { Formic acid } \\
(\mathbf{0 . 7 5 \% )}\end{array}$ & $1733.91^{\mathrm{b}} \pm 53.02$ & $734.09^{\mathrm{a}} \pm 26.34$ & $947.24^{\mathrm{a}} \pm 5.31$ & $1.29^{\mathrm{a}} \pm 0.05$ & $0.77^{\mathrm{a}} \pm 0.05$ \\
\hline $\begin{array}{c}\text { Formic acid } \\
(\mathbf{1 . 0 \%})\end{array}$ & $1743.64^{\mathrm{b}} \pm 47.25$ & $772.14^{\mathrm{a}} \pm 21.62$ & $1055.90^{\mathrm{b}} \pm 2.18$ & $1.37^{\mathrm{a}} \pm 0.04$ & $0.73^{\mathrm{a}} \pm 0.04$ \\
\hline P value & $<0.0001^{* *}$ & $<0.0001^{* *}$ & $<0.0001^{* *}$ & $<0.0057^{*}$ & $<0.0042^{*}$ \\
\hline
\end{tabular}

$\mathrm{a}, \mathrm{b}$ and c Means $( \pm \mathrm{SE})$ in the same column with different superscripts are significantly different $* *$ is high significance $*$ is significance

Body weight (BW): The birds were received formic acid at all level at all level had the lowest BW (p<0.0001) as compared with the control groups. The lowest BW $(1733.9 \mathrm{~g})$ was recorded for birds were received formic acid level of $0.75 \%$.

Body weight gain (BWG): The data shown in table (2) cleared that the formic acid at level of 0.5 and $1.0 \%$ had improved BWG $(\mathrm{p}<0.0001)$ the result in contrast obtained at level of $0.5 \%$ compared with control group.

Feed Consumption (FC): The results obtained from table (2) explained thatthere is no significant differences $(\mathrm{p}<0.0001)$ between the FC of control group and formic acid at level of $1.0 \%$. The differences of FC between birds were received formic at levels of 0.5 and $0.75 \%$ were significantly decreased $(\mathrm{p}<0.0001)$ as compared with the other groups.

Feed conversion ratio (FCR): Fed formic acid at levels of 0.75 and $1.0 \%$ had significantly improved $(\mathrm{P}<0.0057)$ the FCR as compared with control group. No significant differences detected of FCR between birds were received formic acid at level of $1.0 \%$ and control group.

Table 3: The effect of formic acid on Lipid profiles of the studied broiler chickens

\begin{tabular}{|c|c|c|c|}
\hline Parameter & Control & Formic acid & $P$ value \\
\hline TCHOL (mg/dl) & $65.04 \pm 4.14$ & $65.17 \pm 4.14$ & -------- \\
\hline HDL (mg/dl) & $50.87^{b} \pm 6.65$ & $29.33^{a} \pm 6.65$ & $<0 . \cdots \mid * *$ \\
\hline LDL (mg/dl) & $14.17^{a} \pm 8.51$ & $35.84^{b} \pm 8.51$ & $<0 . \cdots \mid * *$ \\
\hline TG (mg/dl) & $47.80 \pm 20.69$ & $48.00 \pm 11.94$ & $<0.561$ \\
\hline
\end{tabular}

$\mathrm{a}, \mathrm{b}$ and c Means $( \pm \mathrm{SE})$ in the same row with different superscripts are significantly

** is high significance 
HDL cholesterol: The results obtain from table (3) cleared that there is significantly increased ( $\mathrm{P}<0.0001)$ of HDL cholesterol, in formic acid treated group.

LDL cholesterol: The results obtain from table (3) indicated that the formic acid had increased ( $\mathrm{P}<0.0001)$ LDL cholesterol compared with control group.

Triglycerides (TG): The results of triglycerides (TG) indicated that no significance difference $(\boldsymbol{P}<\mathbf{0 . 0 0 0 1})$ between formic acid compared with the control group.

Table 5: The antibacterial effect of formic acid

\begin{tabular}{cccc}
\hline Parameter & Control & Formic acid & P value \\
\hline $\begin{array}{c}\text { Bacteria population } \\
(\mathbf{0 . 5 \% )})\end{array}$ & $2.85 \times 10^{6}$ & $1.0 \times 10^{6}$ & ----- \\
\hline $\begin{array}{c}\text { Bacteria population } \\
(\mathbf{0 . 7 5 \% )})\end{array}$ & $2.85 \times 10^{6}$ & $4.5 \times 10^{6}$ & ----- \\
\hline $\begin{array}{c}\text { Bacteria population } \\
(\mathbf{1 . 0 \%})\end{array}$ & $2.85 \times 10^{6 \mathrm{~b}}$ & $8 \times 10^{4 \mathrm{a}}$ & $<0.001^{* *}$ \\
\hline
\end{tabular}

$\mathrm{a}, \mathrm{b}$ and $\mathrm{c}$ Means $( \pm \mathrm{SE})$ in the same row with different superscripts are significantly $* *$ is high significance

The antibacterial effect of formic acid was also observed in the present study (Table 5) in which significantly $(\mathrm{p}<0.001)$ reduction in total bacterial and gram negative bacterial counts in broiler chicken received formic acid at level of $1.0 \%$. 
Table 4: Carcass parts as affected by formic acid supplementation

\begin{tabular}{|c|c|c|c|}
\hline $\mathrm{P}_{\text {Parameter }}^{\text {Treatments }}$ & Control & Formic acid & $P$ value \\
\hline Live body weight & $2095^{\mathrm{a}} \pm 102.25$ & $1964^{b} \pm 87.15$ & $<0.001 * *$ \\
\hline $\begin{array}{l}\text { Dressed carcass (g) } \\
\text { (including giblets) }\end{array}$ & $1551.66^{a} \pm 74.12$ & $1432.50^{b} \pm 52.41$ & $<0.007 * *$ \\
\hline Chilled carcass (g) & $1588.33^{a} \pm 74.92$ & $1476.67^{b} \pm 74.93$ & $<0.001 * *$ \\
\hline Heart (g) & $9.73 \pm 7.51$ & $9.08 \pm 5.31$ & $<0.743$ \\
\hline Liver (g) & $39.47^{b} \pm 5.09$ & $32.20^{\mathrm{a}} \pm 3.60$ & $<0.0226 *$ \\
\hline Gizzard (g) & $42.84^{b} \pm 3.52$ & $31.6^{\mathrm{a}} \pm 2.98^{\mathrm{a}}$ & $0.004 *$ \\
\hline Kidney (g) & $2.83^{a} \pm 0.39$ & $1.97^{b} \pm 0.27$ & $<0.006^{*}$ \\
\hline Spleen (g) & $37.47 \pm 0.99$ & $40.20 \pm 0.70$ & $<0.235$ \\
\hline Bursa (g) & $1.47^{\mathrm{a}} \pm 0.64$ & $4.15^{b} \pm 0.45$ & $<0.001 * *$ \\
\hline Fat pad $(g)$ & $13.87^{b} \pm 3.78$ & $20.18^{a} \pm 2.93$ & $<0.004 *$ \\
\hline Total fat $(\mathrm{g})$ & $46.17 b \pm 8.58$ & $64.62 a \pm 9.38$ & $<0.0267 *$ \\
\hline $\begin{array}{l}\text { Breast (g) including sternum } \\
\text { bone }\end{array}$ & $540.00 \pm 31.61$ & $510.00 \pm 25.81$ & 0.325 \\
\hline Breast yield (g) & $460.00^{\mathrm{a}} \pm 29.95$ & $431.67^{b} \pm 24.45$ & $0.0417 *$ \\
\hline Feet \& Shank (g) & $86.67^{\mathrm{a}} \pm 4.97$ & $71.67^{b} \pm 3.52$ & $<0.0692 *$ \\
\hline Drumstick (g) & $220.00 \pm 15.84$ & $218.33 \pm 12.93$ & $<0.4295$ \\
\hline Femurs (g) & $380.00 \pm 16.86$ & $368.33 \pm 13.77$ & $<0.195^{*}$ \\
\hline Back (g) & $145.00^{b} \pm 16.88$ & $146.67^{b} \pm 13.78$ & $<0.534$ \\
\hline
\end{tabular}

a, b and c Means $( \pm$ SE) in the same row with different superscripts are significantly different $* *$ is high significance $*$ is significance 
Dressed carcass (including giblets): The dressed carcass of formic acid treated groupt was significantly lower than the control group. The same trend was observed in the chilled carcass values.

Breast yield: The average of breast weight of formic acid treated group was significantly decreased $(\mathrm{p}<0.0025)$ when compared with the control group.

Liver weight: Formic acid had decreased $(\mathrm{P}<0.0226)$ the lever weight by $18 \%$ as compared with the control group.
Gizzard weight: Formic acid decreased $(\boldsymbol{P}<0.004)$ the gizzard weight by $26 \%$ as compared with the control group.

Fat pad: The average of fat pad of formic acid treatment was numerically significantly higher $(\mathrm{p}<0.004)$ as compared with control group.

Bursa weight: The average of bursa weight of formic acid treatment was numerically significantly higher $(\mathrm{p}<0.001)$ by $182 \%$ as compared with the control group.

Table 6: Comparison between chemical composition of carcass meat of the studied broiler chickens.

\begin{tabular}{cccc}
\hline & Control & Formic acid & P value \\
\hline protein \% & $24.08 \pm 2.13$ & $23.32 \pm 1.05$ & $<0.362$ \\
\hline Fiber \% & $0.57^{\mathrm{b}} \pm 0.94$ & $0.47^{\mathrm{b}} \pm 0.47$ & $<0.0593^{*}$ \\
\hline Fat \% & $12.94 \pm 4.78$ & $13.32 \pm 2.765$ & $<0.486$ \\
\hline Moister & $68.23 \pm 2.58$ & $68.63 \pm 1.29$ & $<0.327$ \\
\hline Ash & $4.11 \pm 0.97$ & $5.01 \pm 0.56$ & $<0.497$ \\
\hline
\end{tabular}

$\mathrm{a}, \mathrm{b}$ and c Means $( \pm \mathrm{SE})$ in the same row with different superscripts are significantly

$*$ is significance

Table 7: Serum biochemical parameters of broilers fed different experimental diets

\begin{tabular}{cccc}
\hline Parameter & Control & Formic acid & P value \\
\hline pH & $7.09 \pm 0.08$ & $6.88 \pm .09$ & $<0.274$ \\
\hline Glucose $(\mathbf{m g} / \mathbf{d l})$ & $207.00^{\mathrm{a}} \pm 25.72$ & $156.67^{\mathrm{b}} \pm 14.85$ & $<0.058^{*}$ \\
\hline Total protein $(\mathbf{g} / \mathbf{L})$ & $26.04 \pm 4.12$ & $29.76 \pm 4.14$ & $<0.0437^{*}$ \\
\hline Globulin $(\mathbf{g} / \mathbf{L})$ & $14.75^{\mathrm{a}} \pm 1.22$ & $16.48^{\mathrm{b}} \pm 1.14$ & $<0.036^{*}$ \\
\hline Albumin $(\mathbf{g} / \mathbf{L})$ & $11.29^{\mathrm{a}} \pm 1.01$ & $13.28^{\mathrm{b}} \pm 1.17$ & $<0.286^{*}$ \\
\hline A/G ratio & $0.77^{\mathrm{a}} \pm 0.11$ & $0.82^{\mathrm{b}} \pm 0.11$ & $<0.028^{*}$
\end{tabular}

$\mathrm{a}, \mathrm{b}$ and $\mathrm{c}$ Means $( \pm \mathrm{SE})$ in the same row with different superscripts are significantly

$*$ is significance 


\section{DISCUSSION}

Cumulative feed consumption was found decreased $(p<0.0001)$ in formic acid group compared to control group (Table 2). Vogt et al. (1979) reported that the reduction in the feed intake might be due to the strong taste associated with the formic acids which would have decreased the palatability of feed, thereby reduced feed intake. Runho et al. (1997) observed that formic acid improved significantly feed: gain ratio in broiler chickens when it was included in the diet from 0.25 to $1 \%$, because a reduction of consumption was noticed, but growth was significantly decreased $(p<0.001)$. The performanceenhancing effects of organic acids in poultry do not appear to be as pronounced as in pigs (Langhout, 2000).

Similar results were found by Leeson et al. (2005) who reported reduction in the feed consumption in groups fed butyric acid supplemented diets compared with the group fed control diet. Chicks fed the diets supplemented with formic acids at level of 0.75 and $1 \%$ showed a significant $(\mathrm{p}<0.001)$ improved in the FCR as against the chicks fed control diet. The improvement in FCR could be possibly due to lesser feed intake resulting in increased body weight gain because of better utilization of nutrients in the birds fed formic acids supplemented diet. These results are in agreement with the reports of Vogt et al. (1981) who reported that organic acids improved the FCR in broiler chicken and Adil et al. (2010, 2011b) who found that the highest weight gains were achieved in the birds fed 3\% fumaric acid as compared to the group fed diet supplemented with $3 \%$ lactic acid. Chicks fed the diet supplemented with organic acids showed a significant $(\mathrm{P}<.05)$ improvement in the FCR as against the chicks fed the control diet.
Results indicated that the birds fed formic acid at level of 0.75 and $1.0 \%$ in water had higher BWG $(\mathrm{p}<0.001)$ at 35 days of age compared to control group (Table 3). These results are in agreement with Owens et al. (2008) who reported that improved body weight gains in broiler chicken fed organic acid supplemented diet. Also there was decrease in dressed carcass and breast yield while, increased total fat and bursa weight.

The formic acid had worst effects $(\mathrm{p}<0 . \cdots 1)$ on lipid profile through increasing LDL and TG levels while decreasing HDL level as showed in table (3). These results may be due to increase the total fat of carcass. The results related to carcass part (Table 4) rivaled supplemented formic acid in water had significantly decreased breast yield $(p<0.0417)$ and dressed carcass weight $(\mathrm{p}<0.007)$.

The antibacterial effect of formic acids was also observed in the present study (Table 4).A significant $\quad(\mathrm{p}<0.001)$ reduction in the caecal viable and coliform counts in birds fed formic acid at level of $1 \%$ was recorded. Similar effects were observed by Owens et al. (2008) and Pirgozliev et al. (2008) reporting significantly $(p<0.05)$ reduced total viable coliform numbers in the ileum and caecum of broiler chicken due to organic acid supplementation. Gunal et al. (2006) also reported that the use of organic acid mixture significantly decreased the total bacterial and gram negative bacteria. (Moharrery and Mahzonieh 2005) recorded decrease in E. coli population in the intestines of broiler chicken with malic acid. Hamed and Hassan (2013) reported that a significant $(\mathrm{P}<.5)$ reduction in total bacterial count in ceca was observed in both the groups treated with acetic acid (3 $\mathrm{mL} / \mathrm{L})$ and organic acid mixture $(3 \mathrm{~mL} / \mathrm{L}$; acetic acid, phosphoric acid, lactic acid, 
fumaric acid and tartaric acid), which were administered through drinking water to Japanese quails at 7 days post infection as compared to the non-treated group. These studies explained that the key basic principle of the mode of action of organic acids on bacteria is that non-dissociated organic acids can penetrate the bacteria cell wall and disrupt the normal physiology of certain types of bacteria that we call ' $\mathrm{pH}$ sensitive' meaning that they cannot tolerate a wide internal and external $\mathrm{pH}$ gradient. Furthermore, the organic acids in poultry might have a direct effect on the gastrointestinal tract (GIT) bacteria population, reducing the level of some pathogenic bacteria and mainly controlling the population of certain types of bacteria that compete with the birds for nutrients.

The effect of dietary supplementation of different levels of formic acid on carcass characteristics and none-carcass components are presented in (Table 4). Dressed carcass weight (g) was significantly decreased $(\mathrm{P}<0.007)$ in the group fed diet supplemented with formic acid compared to the group received control diet. In contrast Garciá et al. (2007) reported that the carcass, right breast and right thigh yields of broilers at 49 days of age were unaffected by supplementation of formic acid $(0.5 \%$ or $1.0 \%)$.

In the current study, Liver, gizzard and kidney weight, were significantly decreased $(\mathrm{P}<0.007)$ when the broilers fed different levels of formic acid compared to the control diet; however, the heart and spleen weight were not affected. the reducing effect of formic acid on liver and gizzard weight could be attributed in part to the partial hydrolysis and destruction of cell wall components of feed ingredients, whereby reduce the grinding action of gizzard and its relative weight (Leeson et al., 2005; Jahanian and Golshadi, 2015).
On the other hand, the antibacterial effect of organic acid is believed to take mainly place in the upper part of the digestive tracts like crop and gizzard (Canibe et al., 2001). Therefore, decrease in gizzard weight could be explained in part by the decrease in microbial populations of upper parts by dietary organic acid supplementation (Dehghani-Tafti and Jahanian, 2016).

The $\mathrm{pH}$ value in the crop and caeca was decreased but the values were not significant $(\mathrm{p}<0.001)$ in caecum agreeing with the results of Waldroup et al. (1995) who reported that the addition of lactic acid at a concentration from 0.25 to $2 \%$ or formic acid from 0.5 to $2 \%$ to broiler diet had no effect on caecal $\mathrm{pH}$. The $\mathrm{pH}$ values in the crop and caeca got reduced as the concentration of dietary organic acids increased, but the values were within the physiological $\mathrm{pH}$ range. Bolton and Dewar (1964) found that the effects of organic acids down the digestive tract gets diminished because of reduction in the concentration of acids as a result of absorption and metabolism, thus justifying the present findings of significantly decreased $\mathrm{pH}$ in the crop and not in the caeca. Caecal $\mathrm{pH}$ did not decrease much but there was significant $(p<0.001)$ reduction in the number of caecal microflora which could be plausibly due to the reduced entry of pathogenic bacteria from the upper parts of GIT (crop) into the intestines of broiler chicken. The lowered $\mathrm{pH}$ is conducive for the growth of favourable bacteria simultaneously hampering the growth of pathogenic bacteria which grow at relatively higher The effect of dietary supplementation of different levels of formic acid on carcass characteristics and none-carcass components are presented in (Table 4). Dressed carcass weight (g) was significantly decreased $(\mathrm{P}<0.007)$ in the group fed diet supplemented with formic 
acid compared to the group received control diet. Ghazala et al. (2011) reported that dietary $0.5 \%$ of formic acid and $0.75 \%$ of acetic or $2 \%$ citric acid improved both $\mathrm{ME}$ and nutrient digestibility, crude protein $(\mathrm{CP})$, ether extract $(\mathrm{EE})$, crude fibre $(\mathrm{CF})$ and nitrogen-free extract (NFE) of broiler diets. Moreover, Hernández et al. (2006) and Garciá et al. (2007) reported that supplementation of formic acid $(0.5 \%$ or $1.0 \%$ ) in broiler finisher diet was found to improve apparent ileal digestibility (AID) of dry matter (DM) $(67.8 \%$ or $68.8 \%$, respectively) and $\mathrm{CP}(72.5 \%$ or $73.5 \%$, respectively) as compared with control (56.4\% DM and $60.7 \% \quad \mathrm{CP})$. Similarly, $2 \%$ citric acid in the broiler diet also increased the retention of DM, CP and neutral detergent fiber (Ao et al., 2009).

In the present study, liver, gizzard and kidney weight, were significantly decreased $(\mathrm{P}<0.007)$ when the broilers fed different levels of formic acid compared to the control diet; however, the heart and spleen weight were not affected. the reducing effect of formic acid on liver and gizzard weight could be attributed in part to the partial hydrolysis and destruction of cell wall components of feed ingredients, whereby reduce the grinding action of gizzard and its relative weight (Leeson et al., 2005; Jahanian and Golshadi, 2015). On the other hand, the antibacterial effect of organic acid is believed to take mainly place in the upper part of the digestive tracts like crop and gizzard (Canibe et al., 2001). Therefore, decrease in gizzard weight could be explained in part by the decrease in microbial populations of upper parts by dietary organic acid supplementation (Dehghani-Tafti and Jahanian, 2016).

Due to $\mathrm{pH}$ reducing properties and direct antimicrobial effect, formic acids might have resulted in inhibition of intestinal bacteria leading to the reduced bacterial competition with the host for available nutrients and diminution in the level of toxic bacterial metabolites as a result of lessened bacterial fermentation resulting in the improvement of protein and energy digestibility, thereby ameliorating the weight gain and performance of broiler chicken. In conclusion, formic acid supplementation had positive effect in improving the performance in terms of body weight gain and FCR. The reduction in the $\mathrm{pH}$ value of various GIT segments.

Serum proteins are mainly synthesized in the liver, and, among other functions, maintain blood volume through the colloidal osmotic effect, buffer blood $\mathrm{pH}$, transport hormones and drugs, participate in cell coagulation, catalyze chemical reactions (enzymes), regulate the metabolism (hormones), and participate in the body defense against foreign agents (Melillo, 2013).

The higher total protein concentration determined in the serum of formic acid group compared with control groups is attributed to their higher albumin values, as globulin values were statistically similar (Table 7). According to Harr et al. (2002), serum total protein values of broilers tend to be lower than those of mammals, ranging from 25.00 to $45.00 \mathrm{~g} / \mathrm{L}$.

Albumin values were higher in formic acid group than in control birds (Table 7 ). The main functions of albumin are the transport of several molecules and the maintenance of blood oncotic pressure (Melillo, 2013).

The higher globulin values determined in formic acid group suggest increased globulin levels of in broilers submitted to formic acid against control group with values of $16.48 \mathrm{~g} / \mathrm{L}$ and $14.75 \mathrm{~g} / \mathrm{L}$ in the control group. 
The A/G ratio values of formic acid group were higher than those of control group due to the higher albumin concentration in formic acid group. When this ratio is reduced, there may be hypoproteinemia, and may indicate acute or chronic inflammatory processes due to the elevation of globulins (Lumeij, 1997).

\section{CONCLUSION}

The results of the current study concluded that formic acid supplementation at level of 0.75 and $1 \%$, had a beneficial effect on the Performance of broiler chicken. Formic acid significantly and increased BWG and FCR at level of Organic acids improved nutrient at level of at level of 0.75 and $1 \%$ by increasing the nutrients and endogenous nitrogen losses, by lowering the incidence of subclinical infections and secretion of immune mediators, and by reducing production of ammonia and other growthdepressing microbial metabolites. Formic had acid benefit is related to uncontrolled variables such as buffering capacity of dietary ingredients, presence of other antimicrobial compounds. Additional research can clarify the role and management of these factors.

\section{REFERENCES}

Abdel-attah, S.A.; EI-Sanhoury, M. H.; EIMednay, N. M. and Abdul-Azeem, F. (2008): Thyroid activity of broiler chicks fed supplemental organic acids, International Journal of Poultry Science, , 7, 215-222

Abdel-Azeem, F.; El-Hommosany, Y.M. and Nematallah, Ali, G.M. (2000): Effect of citric acid in diets with different starch and fiber levels on productive performance and some physiological traits of growing rabbits. Egyptian Journal of Rabbit Science 10, 121-145.
Abdo, M.A. (2004): Efficacy of acetic acid in improving the utilization of low protein-low energy broiler diets. Egypt. Poult. Sci. 24, 123-141.

Adil, S.; Banday, T.; Bhat, GH.; Salahuddin, M.; RaquIb, M. and Shanaz, S. (2011b): Response of broiler chicken to dietary supplementation of organic acids. J Central Eur Agric. 12(3): 498-508.

Adil, S.; Ufail, B.; Gulam, AB.; Masood, S. and Manzoor, R. (2010): Effect of dietary supplementation of organic acids on performance, intestinal histomorphology, and serum biochemistry of broiler chicken. Vet Med Int. 2010: 1-7. Article ID 479485.

A.O.A.C.; Association of Official Analytical Chemists, (1996): Official Methods of Analysis, 16th ed. Association of Analytical Chemists, Washington, D. C. 367-384.

Ao, T.; Cantor, AH.; Pescatore, AJ.; Ford, MJ.; Pierce, JL. and Dawson, KA. (2009): Effect of enzyme supplementation and acidification of diets on nutrient digestibility and growth performance of broiler chicks. Poultry Sci. 88: 111-117

Biggs, P. and Parsons, CM. (2008): The effects of several organic acids on growth performance, nutrient digestibility, and cecal microbial populations in young chicks. Poultry Sci. 87: 2581-2589.

Bolton, W. and Dewar (1964): The digestibility of acetic, propionic and butyric acids by the fowl.Br. Poult. Sci. 6:103-105

Canibe, Engberg, R.M. and Jensen, B.B. (2001): An overview of the effect of organic acids on gut flora and gut health, Proc. of the Workshop: Alternatives to Feed Antibiotics and Coccidiostats in Pigs and Poultry (AFAC), Norfa network, October 1316, Oslo, Norway 
Dehghan-Tafti, $N$. and Jahanian, $R$. (2016): Effect of supplemental organic acids on performance, carcass characteristics, and serum biochemical metabolites in broilers fed diets containing different crude protein levels. Animal Feed Science and Technology 211, 109-116.

Dibner, J. and Buttin, P. (2002): Use of organic acids as a model to study the impact of gut microflora on nutrition and metabolism. J. Appl. Poult. Res. 11,453-463

Duncan, D.B. (1955): Multiple range and multiple tests. Biometrics 11: 1- 42.

Fushimi, T.; Tayama, K.; Fukaya, M.; Kitakoshi, K.; Nakai, N.; Tsukamoto, Y. and Sato, Y. (2001): Acetic acid feeding enhances glycogen repletion in liver andskeletal muscle of rats. J. Nutr. 131, 1973-1977.

Garciá, $\quad V . ; \quad$ Catalá-Gregori, $\quad P$.; HernáNdez, F.; Megiás, MD.; and Madrid J. (2007): Effect of formic acid and plant extracts on growth, nutrient digestibility, intestine mucosa morphology, and meat yield of broilers. J Appl Poultry Res. 16: 555-562. doi: 10.3382/japr.2006-00116

Ghazala, AA.; Atta, AM.; Elkloub, K.; Mustafa, MEL. and Shata, RFH. (2011): Effect of dietary supplementation of organic acids on performance, nutrients digestibility and health of broiler chicks. Int $\mathbf{J}$ Poultry Sci. 10(3): 176-184.

Gornowicz, E. and Dziadek, K. (2002): The effects of acidifying preparations added to compound feeds on management conditions of broiler chickens. Ann.Anim. Sci. 1 (Suppl.), 93-96.

Gunal, M.; Yayli, G.; Kaya, O.; Karahan N. and Sulak. O. (2006): The effects of antibiotic growth promoter, probiotic or organic acid supplementation on performance, intestinal microflora and tissue of broilers. Int. J. Poult. Sci. 5(2): 149155

Hamed, DM. and Hassan, AMA. (2013): Acids supplementation to drinking water and their effects on Japanese quails experimentally challenged with Salmonella enteritidis. Res Zool. 3(1): 15-22.

Harr, KE.; Raskin, RE. and McKinsey, JE. (2002): Hematologic and biochemical changes caused by commonly used anticoagulants on macaw (Anodorhynchus sp.) blood over time [abstract]. Vet Clin Pathol.; 31: 157

Hernández, F.; Garciá, V.; Madrid, J.; Orengo, J. and Catalá, P. (2006): Effect of formic acid on performance, digestibility, intestinal histomorphology and plasma metabolite levels of broiler chickens. Br Poultry Sci. 47:50-56

Hersey, J. (1987): Pepsin secretion. In: Physiology of the gastrointestinal tract (Editor L.R. Johnson). New York: Raven Press, 2: 947-957.

Jahania, R. and Golshadi, M. (2015): Effect of dietary supplementation of butyric acid glycerides on performance, immunological responses, ileal microflora, and nutrient digestibility in laying hens fed different basal diets. Livestock Science 178, 228-236.

Kirchgesner, M. and Roth, F.X. (1982): Fumaric acid as a feed additive in pig nutrition. Pig News Info. 3:259-264.

Langhout, P. (2000): New additives for broiler chickens. Feed mix Special: Alternatives to antibiotics. World Poultry-Elsevier. 16(3): 22-27.

Leeson, S. and Summers, J.D. (2005): Commercial Poultry Nutrition, 3rd ed. Nottingham University Press, Nottingham, UK.

Leeson, Namkung, H.; Antongiovanni, M. and Lee, E.H. (2005): Effect of 
butyric acid on the performance and carcass yield of broiler chickens. Poultry Science 84, 1418-1422.

Lumeij, J.T. (1997): Avian clinical biochemistry. Pages 857-883 in Clinical Biochemistry of Domestic Animals. J. J. Kaneko, J. W. Harvey, and M. L. Bruss, ed. Academic Press, San Diego, CA.

Melillo, A. (2013): Applications of serum protein electrophoresis in exotic pet medicine. Veterinary Clinics of North America Exotic Animal Practice; 16(1):211-225.

Moharrery and Mahzonieh, M. (2005): "Effect of malic acid on visceral characteristics and coliform counts in small intestine in the broiler and layer chickens," International Journal of Poultry Science, vol. 4, no. 10, pp. 761-764,

Owens, B.; Tucker, L.; Collins, MA. and McCracken, KJ. (2008): Effects of different feed additives alone or in combination on broiler performance, gut micro flora and ileal histology. British Poultry Science ;49(2):202-212

Patten, J.D. and Waldroup, P.W. (1988): Use of organic acids in broiler diets. Poultry Sci.67: 11781182

Pirgozliev, V.; Murphy, T.C.; Owens, B.; George, J. and McCannin, M.E.E. (2008): Fumaric and sorbic acid as additives in broiler feed. Res. Vet. Sci. 84, 387-394.

Ricke, S C. (2003): Perspectives on the use of organic acids and short chain fatty acids as antimicrobials. Poult. Sci. 82:632-639.

Runho, C.; Sakomura, N.K.; Kuana, S.; Banzatto, D.; Junoqueria, O.M. and Stringhini, J.H. (1997): Usodoacidoorganico (acidofumarico) nasracoes de frangos de corte. Revista Brasileira de Zootecnia, 26:1183-1191.

SAS Institute (1996): SAS User's Guide: Statistics. Version (6.2th ed.) SAS Institute, Inc., Cary NC.

Syed, M.; Mashook, A. and Rehman, S. (1994): The effect of dietary vinegar on the performance of broiler chicks in hot weather. Sarhad J. Agric. 10, 31-34.

Vogt, H S. Matthes; Harnisch, S. and Ristic, M. (1979): Fumaric acid in broiler rations. Arch. Geflugelkd 43:54-60.

Vogt, H.S. Matthes and Harnisch, S. (1981): The effect of organic acids in the rations on the performance of broilers and laying hens. Arch. Geflugelkd 45: 221-232.

Waldrou A.; Kaniawati, S. and Mauromoustakos, A. (1995):

Performance characteristics and microbiological aspects of broiler fed diets supplemented with organic acids. Journal of Food Protection 58: 482-489.

Weinak, M.; Snoeyenbos, G.H. and Smyser, G.F. (1979): A supplemental test system to measure competitive exclusion of salmonellae by native microflora in chicken gut. Avian Diseases 23, 1014-1030. 


\section{تأثير إستخذام بعض الأحماض العضوية على الأداء الإتتاجى لاجاج التسمين \\ حسين عبل الفتاح محمول ، أسامة سامى عفيفى ، محد محروس محدد}

E-mail: hussein1905@yahoo.com_Assiut University web-site: www.aun.edu.eg

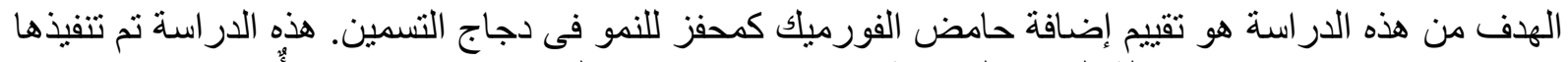

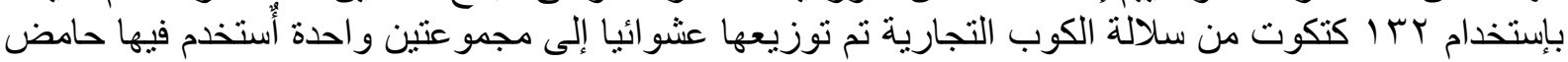

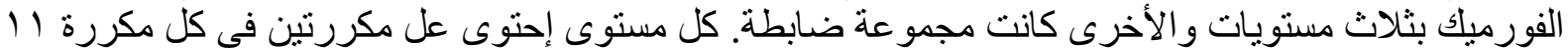

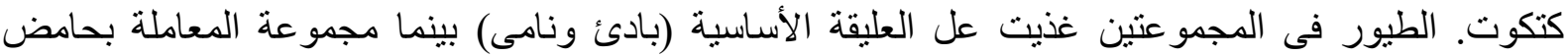

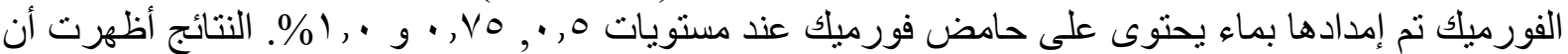

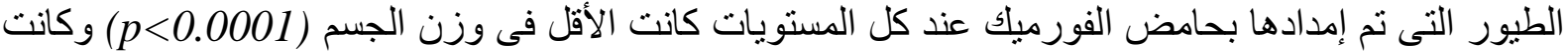

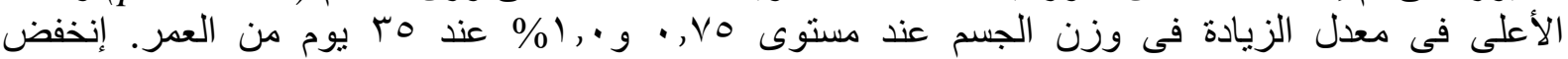
(p>0.0001)

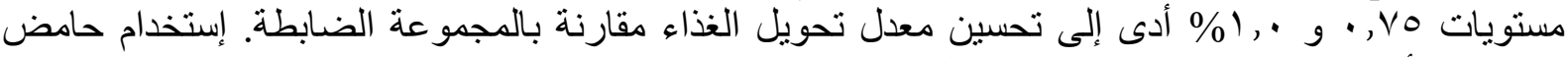
الفورميك أدى إلى إنخفاض وزن محصول لحم الصدر والذبيحة المجهزة وزيادة وزن الدهن الكلى ولى وغدة

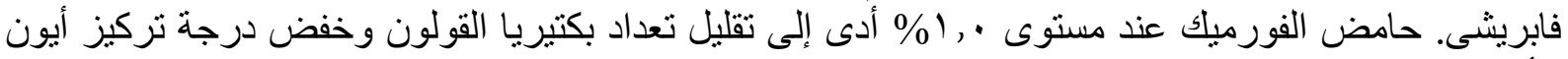

